Doctor of Historical Sciences (Dr. Hab. in History), Professor, Professor of Department of Humanities and Social Disciplines, Poltava State Agrarian Academy

(Poltava, Ukraine), mikola.yakimenko@pdaa.edu.ua ORCID: https://orcid.org/0000-0003-3484-0764

TAmara Sharavara

Doctor of Historical Sciences (Dr. Hab. in History), Professor, Head of Department of Humanities and Social Disciplines, Poltava State Agrarian Academy

(Poltava, Ukraine), 125125.tsh@gmail.com ORCID: https://orcid.org/0000-0002-6370-6663

Svitlana Makarets

Candidate of Historical Sciences (Ph. D. in History), Docent, Docent of Department of Humanities and Social Disciplines, Poltava State Agrarian Academy (Poltava, Ukraine), 1974svitlanam@gmail.com ORCID: https://orcid.org/0000-0002-6844-261X

Yulita Nikolaienko

Candidate of Pedagogical Sciences (Ph. D. in Pedagogy), Docent, Docent of Department of Humanities and Social Disciplines, Poltava State Agrarian Academy

(Poltava, Ukraine), nikolayenko.y@ukr.net ORCID: https://orcid.org/0000-0002-4635-2461

\title{
THE PROBLEM OF LABOUR MIGRATION OF UKRAINIAN PEASANTS AND BURGHERS IN THE INTERNAL POLICY OF RUSSIAN EMPIRE IN THE SECOND HALF OF THE NINETEENTH - EARLY TWENTIETH CENTURIES
}

\begin{abstract}
The purpose of this research is to highlight the results of Russian policy for Ukrainian labour migrants, which is both of theoretical and practical importance, since it enables modern Ukrainian leaders to take into account positive and negative experience of unprivileged classes labour migration in the late 19th and in the early 20th centuries. The research methods are based on the main principles of historicist tradition, scientific objectivity, comprehensive approach and data classification. In order to achieve the purpose the authors use a number of general scientific methods (analysis, synthesis, classification) as well as specific historical methods, such as problematic and chronological, comparative, retrospective and method of periodization. As the result of the research, the authors have made a conclusion about quite high activity of the inhabitants of Dnipro Ukraine in migration movements during the second half of the 19th century and the early of the 20th century due to the lack of land. The economic reasons were predominant for most migrants, as they were unable to satisfy their primary needs within their region. These are general observations. To be more precise, we can determine a certain range of social and economic factors which made direct and indirect impact on stepping up of migration movements on Ukrainian lands of the Russian empire within the period of 1861-1917. These factors include: 1) the lack of land for most small agrarian producers due to the implementation of legislation acts concerning former serf (in 1861), udilni (in 1863) and state peasants (in 1866); 2) small labour market in the late 19th and early 20th century that resulted in agrarian overpopulation of
\end{abstract}


Ukrainian villages (from 7 to 12 million by various estimates); 3) the availability of the special social unprivileged class of kozaks who inhabited Left-Bank Ukraine (with the highest level of migration) and always had a possibility to sell their land and receive some money to move out; 4) the prevailing government ideas concerning Ukrainian people as the best colonization element that is proved by a large number of legislations acts related to so-called "malorosiyski kozaky". Because of fiscal interests, the central power restricted the intention of some part of its citizens to find better resources in other regions of the country for a long period. However, the need for economic growth of remote eastern and south-eastern regions of the empire and necessity for the defence of these territories from aggressive neighbours, e.g. Japan, forced the government to provide more possibilities for labour migrants to move from the densely populated central parts of the country to its borderlands.

Keywords: Russian empire, Ukraine, labour migration, peasants, burghers.

Nowadays the problem of labour migration is very urgent for a number of countries on almost all continents, as it influences both internal and foreign policy and makes all state institutions take measures to develop legal framework for mass migration. In the search for better living conditions millions of people make a decision to move out and often face risks for their health and life. This problem is very urgent for modern Ukraine, since our people are moving to foreign countries and especially European Union to look for better jobs on foreign labour markets.

Due to a number of similar characteristics of labour migration at the turn of the $19^{\text {th }}-20^{\text {th }}$ and $20^{\text {th }}-21^{\text {th }}$ centuries, modern Ukrainian historians, lawyers and economists are interested in the forms and methods used by the state power (central and local) to regulate migration processes after the abolishment of serfdom law and introduction of other reforms during the second half of the $19^{\text {th }}$ century and the early of the $20^{\text {th }}$ century.

For those people who are interested in the history of Ukraine there is a wide choice of scientific works concerning labour migration during the second half of the $19^{\text {th }}$ century and the early of the $20^{\text {th }}$ century. First we should mention such researchers V.Kabuzan ${ }^{1}$, Ya.Boiko ${ }^{2}$, D.W.Treadgold ${ }^{3}$, F.-X.Coguin ${ }^{4}$, and M.Yakymenko ${ }^{5}$. There are also summarizing historiographical works by bodies of state power in solving the problems of agriculture modernization during the

${ }^{1}$ Кабузан В.M. Дальневосточный край в XVII - начале XX вв. (1640-1917): Историкодемографический очерк. - Москва, 1985. - 260 с.; Кабузан В.М. Переселення українщів у Далекосхідний край в 1850-1916 рр. // Український історичний журнал. - 1971. - №2 - С.65-70.

2 Бойко Я.В. Заселение Южной Украины: 1860-1890 гг. (историко-экономическое исследование). - Черкассы, 1993. - 256 с.

${ }^{3}$ Treadgold D.W. Siberian Migration: Government and Peasant in Resettlement Emancipation to the First World War. - Princeton Univ. Press, 1957. - 262 p.

${ }^{4}$ Coguin F.-X. La Siberie: Penplement immigration pansanne an XIX ciecle. - Paris, 1969. $789 \mathrm{p}$.

5 Якименко M.A. Переселення селян з України на Далекий Схід в епоху ринкових реформ кінця XIX - початку XX ст. - Полтава, 2003. - 130 с.; Його ж. Аграрні міграції українського селянства на рубежі XIX-XX ст. - Полтава, 2006. - 144 с.; Його ж. Переселенський рух у Наддніпрянській Україні в роки столипінських реформ (1906-1913рр.). - Полтава, 2009. 148 с.; Якиленко Н.А. Переселенческая политика царизма на Украине и её последствия (18611917 гг.). - Полтава, 2011. - 298 с. 
above-mentioned period and characterize the regional historiography of agrarian relations of Left-Bank Ukraine. Our attention is focused on the sources which deal with the T.Sharavara ${ }^{6}$ and S.Makarets ${ }^{7}$ who pay attention to the activity of the local importance of labour migration of Ukrainians in the internal policy of the tsar government after the abolishment of serfdom law.

Dnipro Ukraine with its 9 gubernias (provinces), such as Kyiv, Podillia, Volyn, Poltava, Kharkiv, Chernihiv, Katerynoslav, Tavriia and Kherson, belonged to the specific regions of the Russian empire in ethnic, social and economic aspects. In order to prove the latter statement it is necessary to mention some peculiarities of the process of serfdom law abolishment, since special laws were adopted for such regions of Ukraine as Left-Bank, Right-Bank and South ${ }^{8}$. The social structure of population was also different in these regions. For instance, Right-Bank Ukraine was inhabited by $34,36 \%$ of noblemen, Left-Bank - by $38,13 \%$ and the South - by $27,51 \%$, so their proportion in these regions was approximately the same. However, the situation with unprivileged classes was quite different, e.g. $52,27 \%$ and $21 \%$ of burghers respectively. The number of former state peasants was estimated as 32,58\% (1 827814 persons) in RightBank Ukraine, 42,76\% (2 399780 persons) in Left-Bank, and 24,66\% (1 383683 persons) in the South. More differences can be observed in the location of the poorest part of unprivileged classes, such as former landlord peasants. Their number was 2128535 persons (50,30\%) in Right-Bank Ukraine, 1487468 persons (42,76\%) in Left-Bank Ukraine and only 615764 persons $(14,55 \%)$ in the South. In comparison with the two above-mentioned categories, the number of udilni peasants (those who served on the lands of the emperor's family) was not significant: 138007 persons (17,48\%) in Right-Bank Ukraine, 326706 persons (42,00\%) in Left-Bank and 324450 persons (41,11\%) in the South. According to the statistics in 1863 burghers was represented by 1575760 persons and former state peasants - by 5611280 persons in 9 gubernias of Ukraine. The number of landlord peasants was slightly lower 4231767 persons. Together with udilni peasants the total number of all peasants and burghers representatives of Ukraine was more than 12 million persons who formed the main migration groups after $1861^{9}$. Apart from most burghers representatives who were engaged in industry, trade and service sector, the main activity for peasants was agriculture and only in some cases crafts. As there are many scientific works about difficult economic conditions for peasants after the reform of the 1860s, in our research we will not pay special attention to buying

${ }^{6}$ Шаравара T.О., Якиленко М.А. Історіографічне дослідження діяльності земств Наддніпрянської України у сфері модернізації сільськогосподарського виробництва періоду другої половини XIX - початку XX ст. // Проблеми історії України XIX - початку XX ст. Вип.VI. - К., 2003. - С.406-411.

${ }_{7}$ Макарець C.B. Регіональна дорадянська історіографія аграрних відносин у губерніях Лівобережної України на рубежі XIX-XX ст. // Збірник наукових праць міжнародної конференції «Наука і сучасність: виклики глобалізації». - Ч.ІІІ. - К., 2013. - С.81-84.

8 Крестьянская реформа в России 1861 г.: Сборник законодательных актов. - Москва, 1954. C.179, 243, 299.

9 Статистический временник Российской империи / Под ред. П.П.Семёнова. - СанктПетербург, 1866. - С.41-51. 
out operation according to the legislation in 1861, which was the basis for reforming udilni (in 1863) and state peasants (in 1866). From our point of view, it is enough to mention agrarian overpopulation of Ukrainian villages and with the help of it we can estimate the number of labour force that was not able to provide their families with all necessary resources on their native land. The commission, set up according to the tsar edict of November 16, 1901 to examine peasants' welfare, estimated the number of "excessive" population as 7624000 persons $^{10}$. These were families unable to find necessary resources to satisfy minimum needs of adults and children. Taking into account the estimation of one of the authors of this article, we can speak about much larger numbers of potential migrants, which were up to 13 million at the turn of the $19^{\text {th }}$ and $20^{\text {th }}$ centuries ${ }^{11}$. In addition, how could a peasant satisfy his needs, when the minimum standard of land property in the central black soil gubernias was 5 desiatynas per a masculine person $^{12}$, but according to the statistics in 1877 its average size was 2,3 desiatynas for former landlord peasants and 4,0 desatynas - for state peasants ${ }^{13}$. Moreover, 7,8\% of all peasants' households did not possess any agricultural land. This was general economic background for labour migration of Ukrainians after 1861 , which was very contradictive in its form and content. On the one hand, the bodies of central and regional power were aware of the lack of land among the most part of small agrarian producers. This was the reason for stimulation of migration processes in the country. However, during almost four decades the tsar government restricted these processes because of fiscal interests. According to the legislation of the 1860s, peasants had to make payments to the treasury for buying out (former landlord peasants) or for the registration of the so-called "ownership records" by state and udilni peasants. We should also take into account the political component of the problem of agrarian migration, which can be observed in the process of colonization and reclamation of the newly joined regions of the Far East, Caucasus and Middle Asia. The abovementioned facts can explain the reasons for the incoherent migration policy of the tsar government, which included both stimulation and restriction of labour migration until the period of Stolypin reforms. As the researcher from Cherkasy Ya.Boiko states, although a peasant was able to leave his community according to the legislation in 1861, it was almost impossible to fulfil all norms of this law ${ }^{14}$. Meanwhile, the

\footnotetext{
10 Материалы высочайше учреждённой 16 ноября 1901 г. комиссии по исследованию вопроса о движении с 1861 г. по 1900 г. благосостояния сельского населения среднеземледельческих губерний сравнительно с другими местностями Европейской России. - I часть. - СанктПетербург, 1903. - С.224.

11 Якиленко М.A. Переселення селян з України на Далекий Схід в епоху ринкових реформ кінця XIX - початку XX ст. - Полтава, 2003. - С.17.

12 Высочайше утверждённое Положение о переселении малороссийских казаков, однодворцев и прочих казённых поселян для поступления в кавказские казачьи линейные войска и полки // Полное собрание законов Российской империи (далі - ПСЗ РИ). - Собр. 1-е. T.VII. - Санкт-Петербург, 1835. - №5630.

13 Якиленко М.A. Переселення селян з України на Далекий Схід в епоху ринкових реформ кінця XIX - початку XX ст. - С.9.

${ }_{14}$ Бойко Я.В. Переселенська політика та переселенське законодавство в Росії (60-80-ті рр. XIX ст.) // Вісник Черкаського університету: Серія «Історичні науки». - Вип.80. - Черкаси, 2005. - C.64.
} 
government began to prepare laws aimed to regulate labour migration in some regions. On May 10, 1862 they adopted the law that provided each migrant from the central regions of the empire including Ukraine with a right to get 20 desiatynas of land in the Northern Caucasus free of charge ${ }^{15}$. In July 1865, the Russian emperor approved the Regulation of the Committee of Ministers about colonization of Altai region with a right of land tenancy and annual payment of 6 rubles for each newly arrived migrant ${ }^{16}$. The similar laws were adopted for migrants from Orenburg ${ }^{17}$, Ufa ${ }^{18}$, Tobolsk, Tomsk ${ }^{19}$ and a number of other eastern and south-eastern regions of the empire. In the 1880s the laws to stimulate migration to the Amur River region were also adopted ${ }^{20}$. The most part of the abovementioned laws, e.g. the migration law of the empire of July 13, 1889, were not widely known, unlike the circular orders of the minister of internal affairs of April 13 and May 4, 1868. The first one gave the right to migrate to Orenburg and Samara gubernias and settle on the state lands only with a special passport $^{21}$, while the second one threatened a prison for those people who would try to leave their place of registration as a taxpayer without permission of the local state administration ${ }^{22}$. Having heard about the circular order of April 13, 1868, published in some regional newspapers ${ }^{23}$, thousands of poor peasants and burghers representatives applied for a permission to migrate, but a lot of them left their home without any documents. For instance, in 1868 the governor of Poltava wrote in his report to the emperor that in late 1867 and early 1868 "they detected the intention among the peasants of Poltava gubernia to migrate to the Caucasus, but appropriate measures were taken to calm people down and provokers were sent to prison" ${ }^{24}$. In some gubernias of Ukraine with a very urgent problem of

15 Высочайше утверждённое Положение о заселении предгорий западной части Кавказского хребта кубанскими казаками и другими переселенцами из России // ПСЗ РИ. - Собр. 2-е. T.XXXVII. - Санкт-Петербург, 1865. - №38256.

16 Высочайше утверждённое Положение Комитета Министров «О водворении в Алтайском округе государственных крестьян» // Там же. - T.XL. - Санкт-Петербург, 1865. - №42353.

17 Высочайше утверждённое Положение Главного комитета об устройстве сельского состояния, объявленное Сенату министром внутренних дел 16-го того же апреля «О мерах по водворению в Оренбургской губернии издавна проживающих там переселенцев из других губерний» // Там же. - T.XLIV. - Санкт-Петербург, 1869. - №46952.

18 Высочайше утверждённое Положение Главного комитета об устройстве сельского состояния «О распространении высочайше утверждённого 9 апреля 1869 года Положения Главного комитета о переселенцах Оренбургской губернии на губернию Уфимскую и на проживающих в сих губерниях чорнозаводских мастеровых казённых и частных заводов и бывших удельных крестьян» // Там же. - T.XLVI. - Санкт-Петербург, 1871. - №49230.

19 Высочайше утверждённое Положение Главного комитета об устройстве сельского состояния, объявленное Сенату министром внутренних дел 19-го того же ноября «О переселенцах Тобольской и Томской губерний, водворившихся там с давнего времени» // Там же. - T.LI. - Санкт-Петербург, 1876. - №56571.

20 Высочайше утверждённое мнение Государственного Совета «О некоторых изменениях в правилах и льготах переселенцам в Приамурский край» // Там же. - Собр. 3-е. - T.II. - СанктПетербург, 1882. - №655.

21 Российский государственный архив социально-политической истории. - Ф.109. - Оп.208. Д.135. - Л.4.

22 Там же. - Ф.730. - Оп.1. - Д.1608. - Л.2.

${ }^{23}$ Полтавские губернские ведомости. - 1868. - 18 мая.

${ }^{24}$ Российский государственный исторический архив (далі - РГИА). - Ф.1281. - Оп.7. Д.21. - Л.23. 
land scarcity, there were people who called peasants to ignore the information from the official representatives of the local state administration, as they concealed the truth about the freedom of migration to the Far East and Siberia. For instance, in December 1869 the peasants of Kaniv povit (district) Trokhym Kostenko and Dmytro Chemerys under the supervision of the former employee of Kyiv district court Petro Chuchynskyi on the behalf of 43 families of their fellow villagers asked the governor of Kyiv to provide necessary documents for migration to Orenburg gubernia. After the refusal, P.Chuchynskyi explained the reason of such behaviour of the bodies of power to peasants. In his opinion, they concealed the real law that provided each family of migrants with 300 rubles as an aid from the treasury. On January 12, 1870 he was arrested as a provoker, but he managed to escape. Hiding out from the police, P.Chuchynskyi continued propagating migration idea. In early March 1872 he organized subscription in Kyiv povit for the peasants willing to migrate to Orenburg region. P.Chuchynskyi introduced himself as a colonel who was sent by the Ministry of internal affairs to form migration groups in Kyiv region and required from one to five rubles for putting in the list of migrants ${ }^{25}$. According to some data, in such a way he hustled about 1200 rubles from trustful peasants ${ }^{26}$.

The inhabitants of Right-Bank Ukraine who belonged to unprivileged classes suffered not only from the mix of laws, but also from the complicated system of social and economic relations in the region. For instance, in the letter of April 21,1870 , the Ministry of state land property informed the governor of Kyiv that "giving free state lands in Orenburg and Samara gubernias can be only for landless people"27. The peasants who possessed some property were not allowed to receive any migration documents, passports and certificates providing rights to search resources beyond their region ${ }^{28}$. The problem was in the form of land ownership in Ukraine, when the youngest son inherited the plot of land after his father's death. His elder brothers were separated immediately after their marriage and without buying some fields or farmyards they became landless. As the governor of Kyiv reported on July 17, 1872, "meanwhile, these landless people live in the region where all peasants are considered owners by law, but they do not have any land property, that is why their migration is natural" 29 .

Labour migration was restricted in different ways by the bodies of state power in Left-Bank Ukraine largely inhabited by kozaks. For instance, on October 8, 1869 , the trustee of state land property in Samara gubernia sent an inquiry to St. Petersburg concerning so-called "Malorosiiski (Ukrainian) kozaky" who considered themselves as landless and submitted documents from volost (district) administrations. After a month, on November 7, 1869, he received the answer, which said that "Malorosiiski kozaky" were landowners according to the law of

${ }_{25}$ Центральний державний історичний архів України, м. Київ. - Ф.442. - Оп.308. Спр.86. - Арк.58.

${ }_{26}$ Там само. - Арк.79.

27 Там само. - Арк.22.

28 Там само. - Арк.24-25.

29 Там само. - Арк.111. 
June 25, 1832, and were not allowed "to settle on state lands" ${ }^{30}$. Under such conditions the only way out was unauthorized change of their residence. According to the statement of L.Lichkov, the clerk of the governor chancery of Kyiv, Volyn and Podillia, migrants sold their property secretly and "at night they set off without any passports. They were often arrested by the police on train departure or at railway stations". As the abovementioned author says, in order not to be caught by the police, migrants took a train in the distance of 100 and more kilometres from their villages ${ }^{31}$.

In the 1880s and 1890s bureaucratic procedures became less complicated only in the government program for colonization and reclamation of Southern Ussuriysk region according to the laws of January 26, 1882, and June 1, 1882. The latter one even provided free transportation of migrants to the Far East on the route Odesa - Colombo - Yokohama - Vladivostok. Because of a huge number of migrants, free transportation was cancelled and candidates for migration had to possess not less than 600 rubles of their own funds. However, only after the beginning of the construction of the Trans-Siberian railway in 1892, which required a large number of non-qualified labour force, migration movements in the Russian empire, including Ukrainian region, become more active. It resulted in the intensive construction of settlements and roads, provision of food and healthcare. In 1896 the Migration administration with all necessary subdivisions was established. Modern Russian historiographers, following their forerunners' traditions of the tsar period, totally disagree with Soviet researchers criticizing the migration policy of the tsar government and praise everything done by the imperial power before $1917^{32}$. However, the truth is that hundreds of thousands of migrants suffered greatly on every stage of their way to desired places - while leaving their homes, travelling a long distance and settling in the far Siberian taiga or waterless steppe of Kazakhstan. For instance, in 1888 thousands of migrants were kept in prison-like quarantine stations in Odesa before sending to the ships of the Volunteer fleet chartered by the state power ${ }^{33}$. If someone had any symptoms of certain diseases, they were not allowed to the ship. Thus, all healthy family members went to Vladivostok, while sick people stayed there for cure and took risks of losing their families forever.

The first migration point on the way from Ukraine to the eastern and south-eastern regions of the empire was in Nizhniy Novgorod. These were barracks built from coarse wood. Another location was Kazan, where barracks suffered from spring floods. Migration point in Tyumen consisted of 10 barracks which housed up to 18000 migrants instead of 4000 according to the sanitary

${ }_{30}$ РГИА. - Ф.385. - Оп.6. - Д.2528. - Л.7.

31 Записка о положении и организации переселенческого дела в Юго-Западном крае / Сост. Л.Личков. - К., 1894. - С.4.

32 Захарова H.В. Колонизация Тобольской губернии в период столыпинской аграрной реформы (1906-1914 гг.): Автореф. дисс. ... канд. ист. наук. - Воронеж, 2004. - 23 с.; Воронов Н.H. Крестьянские переселения и землеустройство в Минусинском уезде на рубеже XIX-XX вв.: Авторед. дисс. ... канд. ист. наук. - Красноярск, 2004. - 24 с.; Горбунова Ю.Ф. Император Николай II как государственный деятель в отечественной историографии (конец XIX - начало XX вв.): Автореф. дисс. ... канд. ист. наук. - Томск, 2004. - 26 с.

33 Державний архів Одеської обл. - Ф.2. - Оп.1. - Спр.1674. - Арк.130. 
norms. Cooked meal promised by the state power was not available. "The earth floor and bed boards were filthy and the air was smelly. There were not enough toilets" ${ }^{34}$. According to the statement of the inspectors of the Ministry of internal affairs, in 1894 approximately 30\% of migrants were ill on the way from Tyumen to Tomsk and among them $7-12 \%$ died without reaching new places ${ }^{35}$. Migrants continued suffering in new locations. In the book "Trips to migrants" a well-known author G.Uspenskiy writes about some settlements, which he observed, "Some black stacks [...] of small size, which do not look like human accommodation, it is impossible to imagine that people can live here. However, they live" ${ }^{36}$. G.Uspenskiy represents some interesting information concerning Ukrainians' appearance. In 1888 he wrote, "migrants from Malorossia (Ukraine) were dressed better than ours, had meals more carefully and at certain time. All people from Malorossia had boots, while Russians were wearing lapti (straw shoes), dirty shirts, pants and dresses" ${ }^{\prime 7}$.

In accordance with the legislation of the late $19^{\text {th }}$ century, all people who had permission documents were allowed to apply for a state loan. It was limited to 200 rubles and had to be paid back within a period of 28 years $^{38}$. During the next years the procedure of providing migration loans was changed several times and its amount depended both on the good will of a certain clerk and the region of agrarian colonization. Anyway, we can state that these loans were not large enough, since according to the official data, to settle and start farming in the Far East, Siberia or Kazakhs steppe, it was necessary to have at least 400-450 rubles apart from the state loan ${ }^{39}$. However, migrants' financial situation was very poor. According to the data of Chelyabinsk registration point, among 882 interviewed migrants' families from Ukraine in 1906-1909 14,8\% did not possess any own funds, $49,1 \%$ had up to 50 rubles, $12,9 \%-51-100 \mathrm{ru}$ bles, $12,3 \%-101-200$ rubles, $8,2 \%-201-500$ rubles, $2 \%-501-1000$ rubles and $0,4 \%$ - over 1000 rubles $^{40}$.

The problem was in the fact that loans were difficult to obtain and borrowers did not get the whole sum of money, but only in some parts. We can make such a conclusion reading the telegram of some Ukrainian migrants sent from the village Fedorivka of Primorsk region to St. Petersburg on March 20, 1910. It says, "we represent 79 households. There is a marshy taiga around. There are only 9 desiatynas of land suitable for cultivation. Further reclamation is impossible because of rainfalls and floods. Only money loans will be able to help till the soil,

${ }^{34}$ РГИА. - Ф.592. - Оп.1. - Д.59. - Л.89.

35 Там же. - Л.83.

36 Успенский Г. Поездки к переселенцам // Его же. Собрание сочинений. - Т.8. - Москва, 1958. - C.389.

37 Там же. - С.266.

38 Правила о выдаче ссуд на домообзаведение, приобретение скота и земледельческих орудий переселенцами, водворяемыми на казённых землях // Россия. Государственный Совет. T.54: Временные организации: Материалы: Журналы по делам департамента гражданских и духовних дел. - Санкт-Петербург, 1901. - [4], VI с., 762, LVI стб.

39 Якименко М.A. Аграрні міграції українського селянства на рубежі XIX-XX ст. - C.77.

${ }^{40}$ Российский государственный исторический архив Дальнего Востока (Томск; далі РГИАДВ). - Ф.19. - Оп.3. - Д.911. - Л.42. 
sow grains and save us from hunger" ${ }^{11}$. Moreover, there was a great number of such telegrams. Another example is the letter sent to the governor of Tomsk on February 2, 1909 by the group of Ukrainian migrants of the village Komarovske (I.Puzyr, L.Matviienko, I.Kulyk, P.Borshch, E.Kyryliuk, K.Bryzytskyi, F.Zozulia, I.Zatula, S.Mamai, H.Dovzhkevych, M.Mysko, A.Balatsko, D.Didenko and F.Balako). It says, "we did not have any land in our native villages and did not sell anything, we borrowed money from other people to get here with a permission. We spent the money given to us (100 rubles) to buy a cow. Our situation is very poor at the moment". They asked to provide them with some more funds, "otherwise we will die from hunger" ${ }^{42}$. In 1910 one of the authors of that time wrote, "200 rubles of a state loan do not significantly influence the economic situation of newly arrived people. As a rule, this loan is provided in parts, 50 or even 10 rubles" ${ }^{\prime 3}$.

After characterizing the forms and content of Ukrainian labour migration of the second half of the $19^{\text {th }}$ and the early of the $20^{\text {th }}$ centuries, we would like to analyze the general scale of agrarian migration and the main colonization regions of that time. Unlike the period of 1896-1917, in the first post-reform decades after the abolishment of serfdom law in 1861 there were no accurate records of labour migrants including about $50 \%$ people of working age ${ }^{44}$. On this account, researchers have to use the data from the population census of the Russian empire in 1897, which provides information about people who were not born in the places where they lived at the time of census and who can be considered as migrants. On the base of this data, in 1978 a researcher form Moscow B.Tikhonov published a monograph describing the general scale of migration processes in the Russian empire ${ }^{45}$. Taking into account scientific appreciation of his work, we also use the data from the census of 1897 in our research of Ukrainian labour migration. According to the census, 1229851 Ukrainians took part in migration processes in the second half of the $19^{\text {th }}$ century. Among them 432495 people $(35,17 \%)$ migrated to southern Ukrainian steppes, $333706(27,14 \%)$ - to the Northern Caucasus, 267357 $(21,73 \%)$ - to the nearest Ukrainian gubernias, $129960(10,57 \%)$ - to Siberia, $33904(2,75 \%)$ - to the Far East and 32429 (2,63\%) - to Kazakhstan ${ }^{46}$. These figures can be considered as minimum, since B.Tikhonov did not take into account the regions where the number of migrants was less than 5000.

During the period of Stolypin reforms the change from the policy of restriction of migration processes to their stimulation resulted in swelling of migrants numbers on the whole territory of the empire and also in Ukraine. Having done some calculations, we receive the following data: in the period of 1896-1917

${ }^{41}$ РГИА. - Ф.391. - Оп.4. - Д.509. - Л.17.

${ }^{42}$ Государственный архив Томской обл. - Ф.239. - Оп.1. - Д.34. - Л.1.

43 Известия областной земской переселенческой организации. - 1910. - №39. - С.88.

44 Переселение в Сибирь из 8-ми губерний Южно-Русской областной земской переселенческой организации за 1912 г.: Семейные переселенцы, ходоки, одиночные переселенцы / Сост. П.М.Новосёлов. - Вып.2. - Полтава, 1917. - С.1.

${ }_{45}$ Тихонов Б.В. Переселения в России во второй половине XIX в.: По материалам переписи 1897 г. и паспортной статистики. - Москва, 1978. - 213 с.

46 Там же. - C.198-205. 
2062381 migrants Left-Bank Ukraine. This number includes 1035862 persons (50,23\%) from Left-Bank Ukraine, 416990 persons (20,22\%) from RightBank and 609529 persons (29,55\%) from the South. We note a comparatively small percent of migrants from Right-Bank Ukraine, although land scarcity in that region was similar to Left-Bank Ukraine. One of the main reasons of this fact is that the tsar government restricted migration from this region because of the predominance of Polish people who were hostile to Russia. A large part of those who left their native places had to come back due to various circumstances. 554169 unfortunate migrants included 26,9\% of Ukrainians. Among them 264029 persons (47,65\%) returned to Left-Bank Ukraine, 171976 persons $(31,03 \%)$ - to the South and 118164 persons $(21,32 \%)$ - to Right-Bank Ukraine ${ }^{47}$. In 1913 a former clerk of Migration Administration S.Bulatov who was made redundant, but actually dismissed because of his disapproval of the government migration policy, wrote to a member of State Duma (parliament) V.Purishkevich, "almost 600000 migrants of Siberia came back to Russia, having sold their land and houses before migration. Now they have neither land nor houses and become homeless" ${ }^{48} .1147$ migrants' families, who left Amur and Primorsk regions in 1906-1908, were interviewed about the reasons for their back migration. The answers were the following: death of the family head $(2,7 \%)$, remote location of their plots of land $(4,2 \%)$, lack of money $(21,88 \%)$, lack of transport routes $(0,69 \%)$, floods $(5,92 \%)$, marchlands $(6,62 \%)$, rocky area $(10,46 \%)$, no free plots of land $(5,05 \%)$, family disagreements $(1,65 \%)$, they did not like the new region $(15,43 \%)$. The other reasons including expensive goods, lack of possibilities to earn money, bad climate etc. made up $26,98 \%^{49}$.

All researchers of agrarian migration agree that, from the economic point of view, mass migration movements in the late $19^{\text {th }}$ and early $20^{\text {th }}$ centuries had a positive effect on the regions of agrarian colonization due to agricultural production growth. However, the regions from which people moved out were negatively influenced by migration in both economic and political aspects. Firstly, Ukraine lost the most active part of its citizens (moreover, we have the same situation nowadays). Secondly, this category of population, angered because of their migration failure, was at the head of antigovernment protests. In this context, we should mention well-known peasants' disorders in Poltava and Kharkiv gubernias in 1902 provoked by those who returned to their native places without money, land and houses. These people considered it to be fair to seize food from landowners to feed hungry elderly people, women and children ${ }^{50}$. Most unfortunate migrants came back to Left-Bank Ukraine, which became the centre of anti-government protests during the next years (1905-190751 and 1917-192152).

47 Сельское хозяйство России в ХХ в.: Сборник статистико-экономических сведений за 19011922 гг. / Под ред. Н.П.Огановского, Н.Д.Кондратьева. - Москва, 1923. - С.32-36.

48 РГИА. - Ф.391. - Оп.5. - Д.1148. - Л.4.

${ }_{49}$ РГИАДВ. - Ф.19. - Оп.3. - Д.914. - Л.293.

${ }^{50}$ Искра. - 1902. - 1 мая.

51 Якименко М.А. Сорочинська трагедія. - К., 1990. - 126 с.

${ }_{52}$ Ревегук В. Селянство Полтавщини в добу Української революції 1917-1921 рр. - Полтава, 2017. $-382 \mathrm{c}$. 
After analyzing a complex of historical facts and studying a large number of archive sources, we make a conclusion about quite high activity of Dnipro Ukraine inhabitants in migration movements in the second half of the $19^{\text {th }}$ and the early of the $20^{\text {th }}$ centuries. The main reason for labour migration was poor economic situation, since it was impossible for peasants and burghers representatives to satisfy their primary needs within their regions. These are general observations. To be more precise, we can determine a certain range of social and economic factors which made direct and indirect impact on stepping up of migration movements on Ukrainian lands of the Russian empire within the period of 1861-1917. These factors include: 1) the lack of land for most small agrarian producers due to the implementation of legislation acts concerning former serf (in 1861), udilni (in 1863) and state peasants (in 1866); 2) small labour market in the late $19^{\text {th }}$ and early $20^{\text {th }}$ century that resulted in agrarian overpopulation of Ukrainian villages (from 7 to 12 million by various estimates); 3) the availability of the special social unprivileged class of kozaks who inhabited Left-Bank Ukraine (with the highest level of migration) and always had a possibility to sell their land and receive some money to move out; 4) the prevailing government ideas concerning Ukrainian people as the best colonization element that is proved by a large number of legislations acts related to so-called "malorosiyski kozaky". Because of fiscal interests, the central power restricted the intention of some part of its citizens to find better resources in other regions of the country for a long period. However, the need for economic growth of remote eastern and south-eastern regions of the empire and necessity for the defence of these territories from aggressive neighbours, e.g. Japan, forced the government to provide more possibilities for labour migrants to move from the densely populated central parts of the country to its borderlands. The experience of mass migrations of Ukrainians in the $19^{\text {th }}-20^{\text {th }}$ centuries is quite useful for the modern leaders of Ukraine. It gives grounds to state that the urgent task for the government of Ukraine and other countries as well is to provide their citizens with high living standards, which will successfully prevent migration processes.

\section{REFERENCES}

1. Boiko, Ya.V. (2005). Pereselenska polityka ta pereselenske zakonodavstvo v Rosii (1860-1880). Visnyk Cherkaskoho universytetu: Seria: Istorychni nauku, 80, 61-75. Cherkasy. [in Ukrainian].

2. Boiko, Ya.V. (1993). Zaseleniie Yuzhnoy Ukrainy: 1860-1890 (istoriko-ekonomicheskoe issledovaniye). Cherkassy. [in Russian].

3. Coguin, F.-X. (1969). La Siberie. Penplement immigration pansanne an XIX ciecle. Paris. [in French].

4. Gorbunova, Yu.F. (2004). Imperator Nikolay kak gosudarstvennyy deyatel $v$ otechestvennoy istoriografii (konets XIX - nachalo XX v.). Tomsk. [in Russian].

5. Kabuzan, V.M. (1985). Dalnevostochnyy kray v XVII - nachale XX vv. (1640-1917): Istoriko-demograficheskiy ocherk. Moscow. [in Russian].

6. Kabuzan, V.M. (1971). Pereselennia urkaiintsiv u dalekoskhidnyi krai v 1859-1916 rr. Ukrainskyi istorychnyi zhurnal, 2, 65-70. [in Ukrainian]. 
7. Makarets, S.V. (2013). Rehionalna doradianska istoriohrafiia ahrarnykh vidnosyn $\mathrm{u}$ huberniiakh Livoberezhnoi Ukrainy na rubezhi XIX-XX st. Zbirnyk naukovykh prats mizhnarodnoi konferentsii "Nauka i suchasnist: vyklyky hlobalizatsii", 81-84. [in Ukrainian].

8. Novosyolov, P.M. (Ed) (1917). Pereseleniye iz 8 guberniy Yuzhno-russkoy oblastnoy zemskoy pereselencheskoy organizatsii za 1912 god. Semeynyye pereselentsy, khodoki, odinochnyye pereselentsy. Poltava. [in Russian].

9. Oganovskiy, N.P. and Kondratyeva, N.D. (Eds) (1923). Selskoye khozyaystvo Rossii $v$ XX veke: Sbornik statistiko-ekonomicheskikh svedeniy za 1901-1922 gg. Moscow. [in Russian].

10. Revehuk, V. (2017). Selianstvo Poltavshchyny $v$ dobu ukrainskoi revoliutsii 1917$1921 \mathrm{rr}$. Poltava. [in Ukrainian].

11. Sharavara, T.O., Yakymenko, M.A. (2003). Istoriohrafichne doslidzhennia diialnosti zemstv Naddniprianskoi Ukrainy u sferi modernizatsii silskohospodarskoho vyrobnytstva periodu druhoi polovyny XIX - pochatku XX st. Problemy istorii Ukrainy XIX - pochatku $X X$ st., VI, 406-411. Kyiv. [in Ukrainian].

12. Tikhonov, B.V. (1978). Pereseleniya v Rossii vo vtoroy polovine XIX v. Po materialam perepisi 1897 g. i pasportnoy statistiki. Moscow. [in Russian].

13. Treadgold, D.W. (1957). Siberian Migration: Government and Peasant in Resettlement Emancipation to the First World War. Princeton Univ. Press.

14. Voronov, N.N. (2004). Krestyanskiye pereselenyia i zemleustroistvo v Minusinskom uezde na rubezhe XIX-XX vv. Krasnoyarsk. [in Russian].

15. Yakymenko, M.A. (2006). Ahrarni mihratsii ukrainskoho selianstva na rubezhi XIX$X X$ st. Poltava. [in Ukrainian].

16. Yakymenko, M.A. (2003). Pereselennia selian z Ukrainy na Dalekyi Skhid v epokhu rynkovykh reform kintsia XIX - pochatku XX st. Poltava. [in Ukrainian].

17. Yakymenko, M.A. (2009). Pereselenskyi rukh u Naddniprianskii Ukraini v roky stolypinskykh reform (1906-1913). Poltava. [in Ukrainian].

18. Yakymenko, M.A. (1990). Sorochynska trahediia. Kyiv. [in Ukrainian].

19. Yakymenko, N.A. (2011). Pereselencheskaya politika tsarizma na Ukraine i yeyo posledstviya (1861-1917). Poltava. [in Russian].

20. Zakharova, N.V. (2004). Kolonizatsiya Tobolskoy gubernii v period Stolypinskoy agrarnoy reformy (1906-1914). Voronezh. [in Russian].

МиколА Якименко

доктор історичних наук, професор, професор кафедри гуманітарних і соціальних дисциплін,

Полтавська державна аграрна академія (Полтава, Україна), mikola.yakimenko@pdaa.edu.ua ORCID: https://orcid.org/0000-0003-3484-0764

TAMAPA ШAPABAPA

докторка історичних наук, професорка, завідувачка кафедри гуманітарних і соціальних дисциплін,

Полтавська державна аграрна академія

(Полтава, Україна), 125125.tsh@gmail.com ORCID: https://orcid.org/0000-0002-6370-6663

Світлана Макарець

кандидатка історичних наук, доцентка, доцентка кафедри гуманітарних і соціальних дисциплін,

Полтавська державна аграрна академія (Полтава, Україна), 1974svitlanam@gmail.com ORCID: https://orcid.org/0000-0002-6844-261X 


\title{
ЮЛІя НІколАєнко
}

кандидатка педагогічних наук, доцентка, доцентка кафедри гуманітарних і соціальних дисциплін,

Полтавська державна аграрна академія

(Полтава, Україна), nikolayenko.y@ukr.net

ORCID: https://orcid.org/0000-0002-4635-2461

\section{ПРОБЛЕМА ТРУДОВОЇ МІҐРАЦІЇ УКРАЇНСЬКИХ СЕЛЯН I МІЩАН У ВНУТРІШНІЙ ПОЛІТИЦІ РОСІЙСЬКОї ІМПЕРІЇ У ДРУГІЙ ПОЛОВИНІ XIX - НА ПОЧАТКУ ХХ ст.}

\begin{abstract}
Анотація. Мета дослідження полягає у висвітленні наслідків російської політики для українських трудових мігрантів, що має не лише суто теоретичне, але і практичне значення, адже дозволяе в наш час ураховувати позитивний та негативний досвід трудової мітрації непривілейованих станів кіния XIX початку XX cm. Методологія дослідження базується на основних принципах історизму, наукової об'єктивності, усебічного та систелного підходу й систематизації джерел. Використано як загальнонаукові (аналіз, синтез, класифбікація), так і спеціальні історичні (проблелно-хронологічний, порівняльноісторичний, періодизаиї̈, ретроспективний) методи дослідження. Автори дійшли висновку про досить високу активність мешканиів Наддніпрянської України в міграційних рухах другої половини XIX-початку XX cm., спричинену мало- та беззелеллям. Загалол визначальними для абсолютної більшості трудових мігрантів були економічні причини, тобто неложливість у межах свого регіону задовольнити основні потреби селянсько-мішанської родини. Соиіально-еконолічні фбактори, шо пряло або побічно впливали на активізацію міграиійних рухів на українських зеллях Російської ілперії в період із 1861 по 1917 рр.: 1) мало- й безземелля основної маси дрібних сільськогосподарських товаровиробників у ході реалізації законодавчих актів щодо колишніх кріпосних (1861 р.), удільних (1863 р.) та державних (1866 р.) селян; 2) вузькість ринку робочої сили у другій половині XIX - на початку XX cm., прялил наслідкол чого стало аграрне перенаселення українського села, яке, за різнили даними, охоплювало від 7 до 12 млн осіб; 3) наявність у губерніях Лівобережної України, де міграції були особливо значущили, такої соціальної категорії непривілейованих станів, як козаки, що завжди мали можливість продажу свойх угідь $i$, відповідно, отримання для переселення певної сули коштів; 4) панування в урядових колах дулки щодо українців як найкращого колонізаційного елеленту, що підтверджується иілою низкою законодавчих актів стосовно поселення так званих "малоросійських козаків". Переслідуючи суто фбіскальні мотиви, иентральна влада тривалий час усіляко обмежувала налагання свойх підданих знайти в інших регіонах краӥни відповідні засоби життедіяльності. Проте потреби економічного розвитку східних і південно-східних окраїн ілперії, а також необхідність захисту їх від зазіхань агресивних сусідів (у толу числі Японіі), змушували урядові кола крок за кроком створювати дедалі більші можливості для руху трудових мігрантів із густозаселених иентральних регіонів Росї.
\end{abstract}

Ключові слова: Російська ілперія, Украӥна, трудова міграція, селяни, лішани. 